\title{
Oko, okulary, autografy - przyczynki do historii literackiej Zygmunta Krasińskiego
}

Teresa Winek

(Instytut Badań Literackich PAN)

\section{ROMANTYCZNY PEJZAŻYSTA}

W I830 roku w pierwszym poszycie „Pamiętnika dla Płci Pięknej” ukazało się bezimienne dzieło: Opisanie jeziora generwskiego Leman. (Wyjątek z listu podróżującego Polaka) ${ }^{I}$. Autorem korespondencji (datowanej: ro listopada r829) był rozpoczynający zagraniczną edukację Zygmunt Krasiński; adresowal ją do pozostawionego w Warszawie przyjaciela, Konstantego Gaszyńskiego, współredaktora przywołanego romantycznego czasopisma. Dzieło epistolograficzne zostało pomyślane jako literackie sprawozdanie $\mathrm{z}$ wędrówki po kraju budzącym zainteresowanie swą wielostronną odmiennością. Choć, jak napisał Juliusz Kleiner, „przyroda nie była [dla Krasińskiego - T.W.] tym pięknem, w którym się wyraz myśli przebija”, czytelniczki czasopisma mogły się czuć usatysfakcjonowane. Krasiński opisywał bowiem wrażenia jak romantyczny wędrowiec, ale próbował też wyrażać samodzielnie swe odczuwanie krajobrazu i nazywać doznania wywołane kontaktem z kulturą innego narodu. Obszerny list, objętości mniej więcej jednej szóstej arkusza, zawiera mnóstwo różnorodnych treści, przywołamy więc tylko niektóre z nich. Jest on stosunkowo wczesnym w naszej literaturze opisem Alp Szwajcarskich³, a szczególnie cenna wydaje się w nim przyjęta perspektywa oglądu:

1 „Spisywanie wrażeń z podróży było w modzie” - stwierdził Juliusz Kleiner (idem, Zygmunt Krasiñski. Dzieje myśli, Lwów 1912, t. 1, s. 24-25). Pierwszą relację z podróży zawarł trzynastoletni Zygmunt Krasiński w liście do ojca z września 1825 roku; opisał w nim wrażenia z wędrówki na Podole. O skłonności przyszłego pisarza do opisywania swych wrażeń podróżniczych świadczą też kolejne jego listy. Zob. też S. Burkot, Polskie podróżopisarstwo romantyczne, Warszawa 1988.

2 J. Kleiner, op. cit., s. 25.

3 Por. S. Burkot, op. cit., rozdz. 5: Pótnoc i Potudnie. 


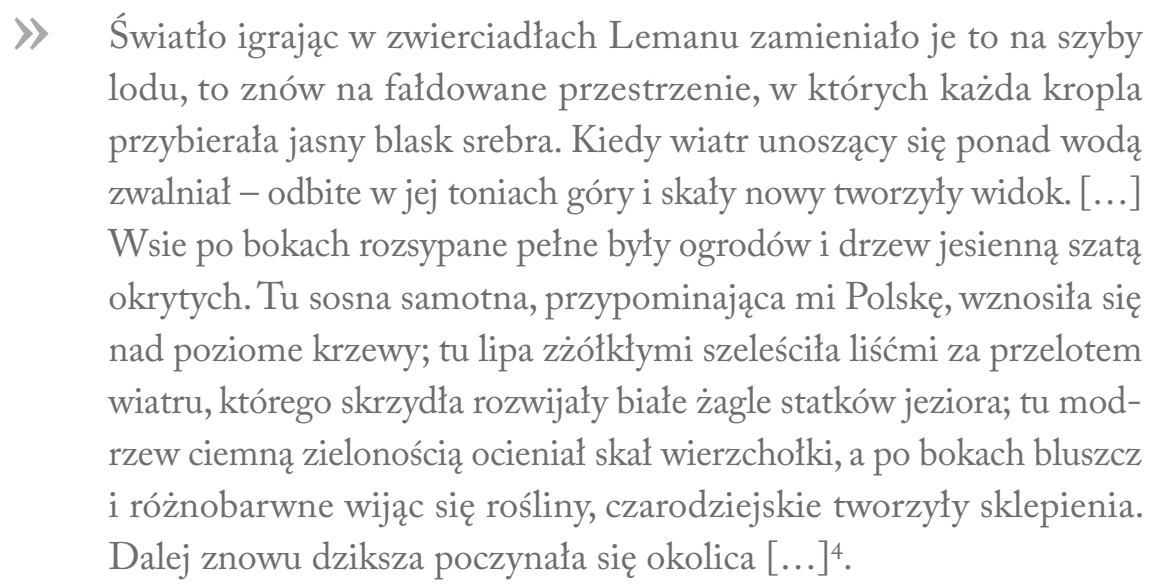

Epistolarny opis - dowód niezwykłych predyspozycji oczu autora i jego wrażliwości na bodźce wizualne ${ }^{5}$ - przynosi rozbudowany zestaw widoków w szwajcarskiej Arkadii; pejzaż oglądany z perspektywy aktywnego obserwatora odsłania swe elementy monumentalne (Mont Blanc), jak też drobiazgi, na przykład: ornamenty wiejskich chat $\mathrm{w}$ dolinie, grę słońca na jeziorze. Przywiązany do szczegółu podróżny dostrzegał kształty, barwy, znaczenie światła w widzeniu, ale wiedział też o ważnym dla romantyków znaczeniu kontrastu (stąd dwie perspektywy oglądu $\left.{ }^{6}\right)$. Przywołał dwie kategorie estetyczne: wzniosłości i piękna - w takiej właśnie kolejności. Nietrudno wskazać estetyczne wzorce Krasińskiego, to opisy z sentymentalnych przewodników, ale wzbogacone elementami nieobecnymi we wcześniejszych relacjach z wędrówek. Dzięki tym oglądom, według Kleinera, Krasiński uświadamiał sobie swój stosunek do przyrody i szukał dla niego własnego wyrazu. Skłonność do opisywania, wywodząca się z właściwej sentymentalizmowi potrzeby ujawniania uczuć oraz indywidualnego przeżywania

4 Z. Krasiński, Listy do Konstantego Gaszyńskiego, oprac. i wstępem poprzedził Z. Sudolski, Warszawa 1971, s. 28. W dalszych odwołaniach: Listy do Konstantego Gaszyńskiego... z podaniem stronicy cytatu.

5 O sprawnym oku przyszłego pisarza świadczą też jego sukcesy jako myśliwego. Krasiński portretowany był wielokrotnie, jeden $\mathrm{z}$ najwcześniejszych obrazów, namalowany w 1826 roku przez Januarego Suchodolskiego (adiutanta generała Krasińskiego), przedstawia kilkunastoletniego Zygmunta w roli typowej dla panicza, czyli wracającego z polowania, ze strzelbą i kuropatwami. Suchodolski lubił malować polowania i sceny rodzajowe, w przypadku portretu Krasińskiego nie można jednak mówić tylko o manierze artystycznej, młody spadkobierca Opinogóry gustował bowiem w myśliwskiej rozrywce i stosunkowo często przemierzał ciechanowskie lasy podczas wiosennych i jesiennych polowań. Jak wiadomo, żeby udanie polować, trzeba mieć wzrok sokoli i takim właśnie mógł się szczycić przyszły autor Nie-Boskiej komedii, skoro, inaczej niż soplicowski opowiadacz, wracał do domu ze zdobyczą. W późniejszym okresie w listach do Gaszyńskiego wspominał te chwile jako jasną część swego życia. Polował też w Szwajcarii i we Włoszech podczas pierwszej podróży, czego dowody zachowały się w listach i wspomnieniach.

6 Zob. M. Korzeniewicz, Romantyczne „widzenie” i „styszenie” swiata w „Uspokojeniu”, „Pamiętnik Literacki” 1979 , z. 2, s. 101-123. 
spotkania człowieka ze światem, była w pewnej mierze typowa dla romantycznego podróżopisarstwa, ale potwierdzała też upodobania i predyspozycje młodego pisarza, widoczne chociażby w pierwszych powieściach: Panu Trzech Pagórków i Agaj-Hanie.

$\mathrm{Na}$ szczególną uwagę zasługuje pojawiający się w korespondencyjnym opisie aż pięć razy motyw oka, naturalny w relacji z oglądu pejzażu, ale zaskakujący kontekstami, w jakich występuje. Oko przywołane zostało już w pierwszym zdaniu opublikowanej części listu - w swej oczywistej funkcji: jako narząd wzroku, umożliwiający poznawanie świata zewnętrznego. Po raz kolejny pojawia się ono w bardziej znaczącym kontekście: oglądającemu Alpy nie wystarcza zmysł wzroku, patrzenie powiązane jest bowiem $z$ odczuciem zdumienia wielkością natury i aby mogło zaistnieć, „trzeba przenieść całą duszę do oka”7. Jest to chyba pierwsza u Krasińskiego tak wyrazista próba łączenia zjawisk fizjologicznych z psychicznymi i duchowymi, wręcz przeświadczenie o ich nierozdzielności. Warto też zwrócić uwagę na opozycyjność tego stanowiska wobec klasycznej Mickiewiczowskiej dychotomii: „czucie i wiara” oraz „szkiełko i oko”. Autor korespondencji przywołuje zresztą w podsumowaniu swej podróżniczej relacji Mickiewiczowski dualizm, nadając mu jednak odmienne znaczenie; według Krasińskiego zaburzenie naturalnego porządku świata następuje wtedy, gdy zostają rozdzielne stanowiska oka i serca: „Oko zajmuje się Lemanem i niebotycznymi górami Helwecji, ale serce wzdycha za Polską" . O konsekwencjach tego rozdwojenia (widzenia okiem fizycznym oraz oczyma pamięci) powiemy w dalszej części artykułu, obecnie zasygnalizujemy jeszcze kolejne realizacje „ocznego” motywu. Nasycony wrażeniami wzrokowymi podróżnik wyznaje, że oko może być zmęczone nadmiarem doznań, przytłoczone bogactwem natury, dlatego z zadowoleniem przyjmuje zapadający zmrok, w którym „słabną

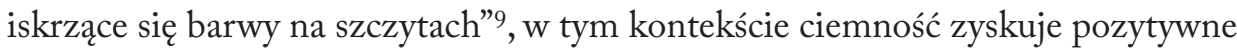
konotacje. Dla romantycznego pejzażysty zaskakujące było także doświadczenie szczególnego zniewolenia przez bodźce wzrokowe i w konsekwencji przekonanie, że nie zawsze oko bywa „instancją” nadrzędną wobec rzeczywistości zewnętrznej, niekiedy jest ono bierne lub wręcz zniewolone przez zmieniającą się naturę, np. wraz ze zmianą nasłonecznienia. Oko patrzącego pozostaje wtedy bezradne wobec docierających doń bodźców.

Zasygnalizowane tu skrótowo motywy związane z okiem i patrzeniem staną się stałym elementem epistolograficznego i literackiego pisarstwa Krasińskiego i zasługują na oddzielne opracowanie, są bowiem istotnym uzupełnieniem roman-

7 Listy do Konstantego Gaszyńskiego..., s. 28.

8 Ibidem, s. 30.

9 Ibidem, s. 29. 
tycznych wątków epistemologicznych i egzystencjalnych; do niektórych z nich powrócimy w dalszej części artykułu. Następne relacje listowne Krasińskiego ze Szwajcarii (a jego korespondencja zarówno z Gaszyńskim, jak też ojcem oraz Henrykiem Reeve'em była wyjątkowo obfita) potwierdzają wzrokową i estetyczną wrażliwość przyszłego pisarza. Zawierają też informacje o licznych zamiarach twórczych.

\section{Сноroba oczu}

Wspaniale rozwijające się plany pisarskie uległy dramatycznemu załamaniu w I832 roku. Listy do ojca, a w większym stopniu do Gaszyńskiego przynoszą wstrząsające relacje o postępującej chorobie: traceniu wzroku. W listach do ojca przebieg choroby opisywany był selektywnie, natomiast szczerze i dramatycznie odkrywał poeta swą sytuację przed przyjaciółmi: Reeve'em, a przede wszystkim Gaszyńskim. Bolesny sygnał nieszczęścia znajdujemy w liście z 9 marca I832 do przebywającego we Francji przyjaciela: „Na pół ślepy jestem i oczy piekielnie mnie bolą”. Informacja taka powracała w każdym następnym liście do Gaszyńskiego: „Na wpół oślepłem, ledwo widzę litery. Bóg da, by to przeszło, bo mi to jest męczarnią"II; „Ledwo mogę pisać" ${ }^{\text {I2 }}$. Choć Ig lutego I832 roku uspokajał ojca diagnozą lekarza, „że to nic inszego, tylko zbytnie utrudzenie; nie mogę ni pisać, ni czytać długo"13, to równocześnie wołał dramatycznie: „Wolałbym nie wiedzieć jaką chorobę niż ten ból oczów, który mnie pozbawia jedynego działania umysłowego, które dotąd w mojej było mocy" ${ }^{\text {"I4 }}$.

Już po kilku tygodniach choroby Krasiński zaczął ją łączyć z innymi dolegliwościami: „Męczę się złożony niemocą oczów i gorączką, do której niejedna przyczyna się przyłożyła" ${ }^{\prime \prime}$. Znamienne dla tego problemu informacje zawiera list z 2 kwietnia I832 roku:

1) Ciąglem słaby na oczy, a oprócz tego mnóstwo rzeczy ciąży mi na sercu i na umyśle. Szczęśliwyś, żeś uszedł widoku, do którego ja spieszyć

10 Ibidem, s. 35 .

11 Ibidem, s. 39, list z 17 marca 1832.

12 Ibidem, s. 41, list z 22 marca 1832.

13 Z. Krasiński, Listy do ojca, oprac. i wstępem poprzedził S. Pigoń, Warszawa 1963, s. 287. W dalszych odwołaniach: Listy do ojca..., z podaniem stronicy cytatu.

14 Ibidem.

15 Listy do Konstantego Gaszyńskiego..., s. 43, list z 27 marca 1832 r. 
muszę; ani spoglądasz na łzy i przekleństwa podbitego. Szczęśliwyś! Przyzwyczajonemu żyć europejskim życiem, okropnie będzie wrócić znów do barbarzyńskiego obyczaju, do udawania, do tajenia swych myśli, do karmienia wśród ciemności zemsty i nienawiści ${ }^{16}$.

Warto zwrócić uwagę na sekwencję znajdujących się w tym cytacie słów: oczy, serce, łzy, przekleństwa, udawanie, tajenie; konsekwencją takiego porządku staje się ciemność, a w niej uczucie zemsty i nienawiści. Istotny dla późniejszej biografii Krasińskiego okaże się motyw ucieczki od bolesnych widoków.

Podejmując zagadnienie choroby wzrokowej Krasińskiego (i jej wpływ na sytuację pisarską poety), wypada zapytać, jak była ona traktowana w istniejącej literaturze przedmiotu. Otóż interesującego nas problemu badacze autora Przedświtu właściwie nie podejmowali. Józef Kallenbach, autor pierwszej dwudziestowiecznej monografii poświęconej dziedzicowi Opinogóry (pisanej pod czujną kontrolą rodziny), zamieścił w niej tylko jedno zdanie: o „kolosalnym oczytaniu młodzieńca, przechodzącym po prostu zwykłą miarę ludzką i doprowadzającym Krasińskiego niemal do utraty wzroku" ${ }^{\text {"T7 }}$.Juliusz Kleiner w swej pracy o dziejach myśli autora Przedświtu wspomina kilkakrotnie o jego „zagrożeniu ślepotą" ${ }^{\text {"18 }}$, interesuje go jednak jedynie znaczenie tego cierpienia w rozwoju osobowości rodzącego się pisarza. Zbigniew Sudolski napisał nieco więcej: „Cierpienia moralne i fizyczne tego okresu [lat I831-I832T.W.] odbiły się bardzo na stanie zdrowia poety, widoczne to było zwłaszcza we wzmagającej się od lutego I832 chorobie oczu"'19. Marginalnie traktuje też to bolesne doświadczenie poety Marek Bieńczyk w swym Czarnym człorwieku ${ }^{20}$, omawiając za to niemal z naturalistyczną szczegółowością inne, liczne, przypadłości chorobowe Krasińskiego. Źródła choroby poety zasugerował natomiast pierwszy monografista jego życia i twórczości, Stanisław Tarnowski („Że choroba ta rozwinęła się pod działaniem moralnych powodów, walk i tortur przebytych, przypuścić łatwo" ${ }^{21}$ ), najbardziej zaś dociekliwym badaczem okazał się Bronisław Chlebowski; zwrócił on uwagę na sygnalizowany już przez Kallenbacha nadmiar lektur i przedwczesny rozwój intelektualny dziedzica Opinogóry, ale też konflikt wewnętrzny między jego miłością do ojca i rodu a oceną rodzicielskiej roli w wydarzeniach krajowych. Według monografisty ze Stu lat myśli polskiej: „Kolizje sprzecznych popędów, dążeń,

16 Ibidem, s. 45.

17 J. Kallenbach, Zygmunt Krasiński. Życie i twórczość lat mtodych (1812-1838), Lwów 1904, t. 1, s. 278.

18 J. Kleiner, op.cit., s. 79.

19 Z. Sudolski, Krasiński. Opowieś́ biograficzna, Warszawa 1997, s. 130.

20 M. Bieńczyk, Czarny cztowiek. Krasiński wobec śmierci, Warszawa 1990.

21 S. Tarnowski, Zygmunt Krasiński, wyd. 2, Kraków 1912, t. 1, s. 110-111. 
pragnień, pojęć” doprowadziły do „różnorodnych cierpień cielesnych - z których najdokuczliwszym jest ciągle ponawiające się cierpienie oczu, uderzenia krwi do głowy"22. Ta pozytywistyczna diagnoza życia psychofizycznego była wyjątkowo bliska przeświadczeniom samego poety, który z niespotykaną wnikliwością analizował wielorakie aspekty swego życia.

W dalszej części pracy interesuje nas przede wszystkim samoświadomość Krasińskiego, jego ocena i analiza doświadczenia, z którym musiał się mierzyć, jak się okazało, do końca życia. Ważna jest ona przede wszystkim w tym aspekcie, który miał swój wymiar literacki i wpłynął na kształt pisarstwa autora Przedświtu.

Autoanaliza Krasińskiego z początku lat trzydziestych okazuje się imponująca, biorąc pod uwagę, że znacznie poprzedzała datę oficjalnego rozwoju psychologii i psychoanalizy Zygmunta Freuda ${ }^{23}$. Obarczony cierpieniem podróżnik po Szwajcarii jednoznacznie określał źródła swej choroby: „Cierpienia moralne zupełnie ciało moje rozstroiły. Gdybym z Wami był kampanię odbył, byłbym zdrów jak ryba...” ${ }^{24}$ - przekonywał Gaszyńskiego. Czytając jego pisma z i83I roku, dowiadujemy się o straszliwej walce, jaką toczył z sobą samym i ojcem zakazującym mu powrotu na ojczystą ziemię i udziału w powstaniu. Zmaganiom wewnętrznym towarzyszyły objawy somatyczne, o których pisał do ojca:

\ Drogi Papa mi pisze, bym podróżował, uczył się, kształcił i bywał po towarzystwach. Trudno by mi to przyszło do wykonania w stanie, w którym jestem. Cierpienia wjadły się głęboko w moje serce, nieprzerwaną mam gorączkę; czasami czuję, że mi się mózg przewraca, dni moich i nocy nikomu nie życzę... Czytać, pisać mi nie sposób, ledwo dokończyć mogę zaczętej rozmowy. [...] Takiego stanu znieść nie mogę, cząstkami umieram co dzień. Przez Boga! lepiej by było od razu umrzeć i nie męczyć się tyle ${ }^{25}$.

22 B. Chlebowski, Zygmunt Krasiński, w: Wiek XIX. Sto lat myśli polskiej. Życiorysy, streszczenia, wyjątki, pod red. B. Chlebowskiego i in., t. 5, Warszawa 1909, s. 113. O chorobie psychosomatycznej Krasińskiego wspominał ponad pół wieku później Aleksander Wat w niedokończonej pracy: O Krasińskim (Fragmenty), którą podał do druku Jan Zieliński („Twórczość” 1983, nr 12, s.114-121).

23 Początek psychologii jako dyscypliny naukowej wiązany jest z założeniem przez Wilhelma Wundta pracowni psychologicznej w Lipsku w 1879 r. Freud rozpoczął samodzielną praktykę w roku 1886. Na wyjątkową samoświadomość Krasińskiego zwracała uwagę Danuta Danek: „można powiedzieć, że jego twórczość kryje w sobie pewien świat nie tyle zapomniany, co w istocie dotychczas nierozpoznany: właśnie ów świat wiadomości o zawiłościach duszy człowieka. I to właśnie wiadomości tak prekursorskich wobec naszej współczesnej wiedzy psychologicznej o człowieku, że kiedy już je u Krasińskiego dostrzec, to trudno oprzeć się przekonaniu, że miał w sobie geniusz. Geniusz poznania wewnętrznego". (Eadem, Inne spojrzenie na Krasińskiego. Tezy, w: Zygmunt Krasiński. Dylematy egzystencji - problemy biografi, pod red. M. Bizior-Dombrowskiej, Toruń 2014, s. 99).

24 Listy do Konstantego Gaszyńskiego..., s. 52, list 26 maja 1832 r.

25 Listy do ojca ..., s. 226, list z 14 maja $1831 \mathrm{r}$. 
Przyszły dramaturg wspominał też kilkakrotnie o swym lęku przed przyszłością: „serce moje rozdarte ze wszech stron, gdzie się tylko obejrzę, widzę przyszłość czarną" ${ }^{26}$. Wskazał nawet na ten aspekt choroby, który później został określony jako nerwica wegetatywna lub psychosomatyczna: „Od półtora roku już wciąż jestem słaby to na to, to na owo; im bardziej wzrastam w lata, tym lepiej widzę, żem podobnego układu do Papy, to jest, że umysłowe kłopoty wnet na ciało moje

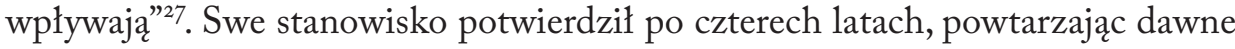
przeświadczenie:

》 wszystkie prawdziwe boleści moje wyszły z serca, tam mieszkają. Cała choroba, która mnie od sześciu lat trapi, jest skutkiem jednego tylko roku, przebytego wśród ciągłej gorączki i rozpaczy. [...] Nerwy rozprężone, $w$ ruch nadprzyrodzony wprawione, już odtąd nie zdołały odzyskać równowagi swojej ${ }^{28}$.

Charakterystyczne, że początek choroby umiejscawia poeta w roku i8zo, czyli czasie wybuchu powstania, choć rzeczywiste jej symptomy ujawniły się dopiero na początku roku $182^{29}$.

Trafność diagnozy Krasińskiego potwierdzają zastosowane przez lekarzy sposoby leczenia jego choroby. Pod koniec marca I832 roku pisarz informował przyjaciela o zabiegach w Genewie: „Zacząłem kurację nieznośną na oczy, kąpiele lodowate, pigułki, maści etc., etc." ${ }^{\circ}$. W drugiej połowie czerwca I832 roku chory przybył do Wiednia, gdzie poddał się diagnozie i kuracji znanego okulisty Fryderyka Jägera ${ }^{3 \mathrm{I}}$,

26 Ibidem, s. 227.

27 Ibidem, s. 293, list z 14 maja 1832 r. O nerwowym podłożu innych chorób fizycznych Krasińskiego pisał Bieńczyk (op. cit., s. 91), przypominając przeświadczenie poety, że nerwy (czyli gangliony) jako siatka włókien to „materialny szkielet ciała, układ zintegrowany, decydujący o związku człowieka $\mathrm{z}$ otoczeniem. Stanowią one wskaźnik istnienia: najmniejsze zakłócenie, jakie je [sic!] dotyka, powoduje globalną, bolesną reakcję organizmu".

28 Listy do Konstantego Gaszyńskiego..., s. 524, list do ojca z 24 kwietnia 1836 r.

29 Bogatą analizę psychoanalityczną zjawiska „niewidzenia” poety z powodu konfliktów zdławionej przez Wincentego Krasińskiego osobowości syna przedstawiła Danuta Danek w tekście Istnienie z kontr-wzajemnościa. Krasiński i dzieciobójstwo (w: eadem, Śmierć wewnętrzna, Gdańsk 2012, s. 41-76). Jarosław Ławski w swych analizach czarnego romantyzmu w twórczości Krasińskiego posłużył się metaforą „oczu za życia powleczonych całunem” (idem, Bo na tym świecie Śmierć. Studia o czarnym romantyzmie, Gdańsk 2008, s. 249).

30 Listy do Konstantego Gaszyńskiego...,s. 41. Dwa tygodnie później informował ojca: „Oczy mnie dość mocno bolą, ale nie jest to żadna organiczna choroba, tylko niemoc pochodząca z ich przetrudzenia; odpoczynkiem wrócę do zdrowia" (list z 15 kwietnia 1832, Listy do ojca..., s. 291). Przywołana wcześniej opinia Kallenbacha ma więc prawdopodobnie swe źródło w tym liście.

31 Zob. komentarz Z. Sudolskiego w: Listy do Konstantego Gaszyńskiego..., s. 37; oraz idem: Krasiński. Opowieśc.... 
by wzmocnić osłabiony organizm; „cały dzień siedzę w pokoju na pół ciemnym [informował ojca - T.W.], jedno wieczorem w karecie wyjeżdżam na przechadzkę; nie mogę ani czytać, ani pisać, zgoła muszę siedzieć z założonymi rękoma i próżnować” ${ }^{2}$. Kuracja trwała do początków sierpnia i nie przyniosła satysfakcjonujących rezultatów. Lekarze zalecali też Krasińskiemu noszenie ciemnoniebieskich okularów, mających chronić zmęczone oczy przed światłem.

Aby zrozumieć stosunek Krasińskiego do choroby oczu oraz źródła jego psychologicznej samowiedzy, powróćmy do wspomnianego już poglądu zawartego w pierwszej epistolarnej relacji z Genewy. Znajduje się w nim znamienne zestawienie oka i serca oraz oka i duszy - nie jako pary opozycyjnej, ale symbiotycznej. W latach trzydziestych będzie ono wielokrotnie powracało w wypowiedziach pisarza, zyska też nowe konteksty. Oto kilka znaczących przykładów: gdy I3 listopada I83ı roku poeta opisywał Koloseum, był przekonany, że zawarła się w nim niemal cała „historia świata”, , ,bo tu po pierwszy raz [sic!] męczennik chrześcijanin i gladiator German, barbarzyniec, zapoznali się, spójrzeli sobie w oczy, oba konający..."33. Io grudnia I83I, wspominając ojcu o spotkaniu z Romanem Załuskim, powstańcem przybyłym do Genewy przez Paryż, podkreślił, że w jego „oczach znać trzy lata więzienia i brzemię dalszych trosków" 34 . Przed powrotem do kraju w I832 roku żywił nadzieję na przemianę sytuacji w ojczyźnie i w swych relacjach z ojcem, trawestując popularne przysłowie o patrzeniu w oczy: „Niechaj się losy srożą, jak chcą, na moim sumieniu wesprzyj się, Ojcze mój, a jeszcze oba zajrzymy w oczy i nieprzyjaciołom i złym losom" 35 .

Wyjątkowe wyznanie związane z chorobą oczu i równocześnie wyzwanie zawiera list z 3 marca I832 roku, przyszły autor Irydiona napisał w nim: „Dreszcz mnie porywa na myśl odwiedzenia Warszawy i Polski, tej drogiej, nieszczęśliwej ofiary, której wyłupiono oczy jak męczennikom starożytnym i kazano się zataczać po drogach" ${ }^{6}$. Jest to chyba najtragiczniejszy obraz polskiego romantyzmu: ojczyzna, której wyłupiono oczy i na pół oślepły poeta, dla którego przypomnienie najeźdźców to bodziec do nieco bezładnej reakcji, stylizowanej według starotestamentowej historii:

\Na tę myśl czuję w sobie gniew święty Mojżesza, kiedy grzebał w piasku pustyni ciało Egipcjanina, ale mniejsza o to, za chwilę jedną u stóp

32 Listy do ojca..., s. 296, list z 16 czerwca 1832 r.

33 Ibidem, s. 265.

34 Ibidem, s. 278.

35 Ibidem, s. 291, list z 15 kwietnia 1832 r.

36 Ibidem, s. 289. 
Ojca dałbym wszystko, zniosę te widoki pełne okropności, tę dumę naigrawającą się z najświętszych uczuć. O Boże, Boże, co też z Polską się stało!37

Jak wiemy, choroba oczu przygniatała Krasińskiego do końca życia ${ }^{38}$. Żadna ze stosowanych kuracji nie przynosiła zadowalających rezultatów ${ }^{39}$. Poeta zrezygnował też z noszenia okularów (prawdopodobnie lekarze widzieli ich nieprzydatność, nieadekwatność wobec schorzenia), inaczej niż jego przyjaciel August Cieszkowski, który nawet do portretów pozował ze szkłami wspomagającymi oczy $^{40}$. W latach trzydziestych XIX wieku okulary były traktowane jako istotna pomoc w usprawnianiu wzroku, pojawiały się też jako znaczący rekwizyt literacki chociażby u Aleksandra Fredry. Szczególną rangę nadał im jednak w swej epopei Adam Mickiewicz. Jak pamiętamy, w roku r8ı2 obyła się w Soplicowie wielka uczta przygotowana przez Wojskiego:

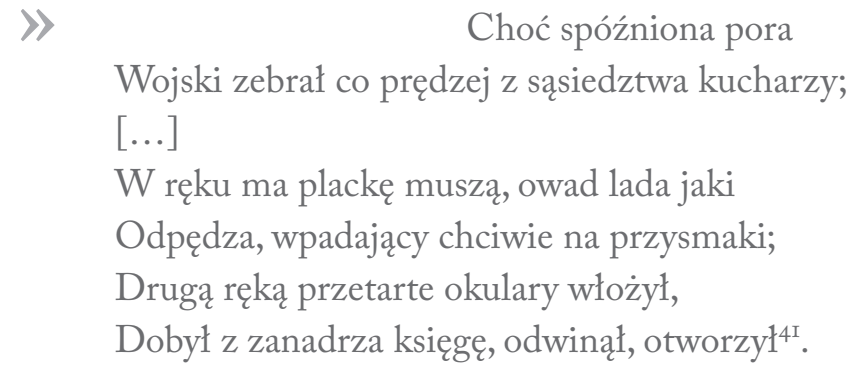

Retoryczne pozostaje pytanie, czy w zmienionej rzeczywistości politycznej narodu Krasiński, analogicznie jak Mickiewiczowski bohater, włożyłby okulary? A może już by ich nie potrzebował? Może jego wzrok odzyskałby sokolą sprawność?

37 Ibidem, s. 289.

38 I tak na przykład, 10 lipca 1837 roku informował z Kissingen: „Chodzić nie mogę, bo mi zaraz tysiąc much czarnych igra przed oczyma" (Listy do różnych adresatów, zebrał, oprac. i wstępem poprzedził Z. Sudolski, Warszawa 1991, t. 1, s. 74), przypominając znany motyw zranionego serca: "Jestem w kryzys życia mojego pod wielu względami. Nieraz będę miał w tych czasach serce rozdarte" (ibidem, s. 75). W kolejnych latach ilość wzmianek o chorobie w listach Krasińskiego malała, częściej raczej informował o chwilowej poprawie wzroku (zob. na przykład Listy do Delfiny Potockiej, t. 1-3, oprac. i wstępem poprzedził Z. Sudolski, Warszawa 1975).

3920 marca 1835 roku pisał do Adama Sołtana: „mi neapolitańskie boskie klima wcale nie pomaga, owszem przymnaża mi boleści oczowych. Mam jakby ciągłą gorączkę" (Listy do Adama Sottana, oprac. i wstępem poprzedził Z. Sudolski, Warszawa 1970, s. 39).

40 Zob. Z. Krasiński, Listy do Augusta Cieszkowskiego, Edwarda Jaroszyńskiego, Bronistawa Trentowskiego, t. 1-2, oprac. i wstępem poprzedził Z. Sudolski, Warszawa 1988.

41 A. Mickiewicz, Dzieta. Wydanie Rocznicowe, t. 4: Pan Tadeusz, oprac. Z.J. Nowak, Warszawa 1998, s. 310-311. 
Według Marka Bieńczyka, poeta pozostał wierny „romantycznemu fantazmatowi, uznającemu chorobę za pełnowartościową formę bytu" ${ }^{22}$, jednak jego relacje o przeżywanym doświadczeniu świadczą, iż było ono ciąłym problemem, słaby wzrok dezorganizował bowiem między innymi jego życie literackie.

\section{KONSEKWENCJE CHOROBY}

Istotna dla historii literatury okazuje się więc odpowiedź na pytanie, jak Krasiński radził sobie $z$ doznawaną codziennie chorobą oczu i jaki wpływ miała ona na jego pisarstwo ${ }^{43}$. Poeta wielokrotnie skarżył się, że sytuacja zdrowotna utrudniała mu udział w życiu towarzyskim. I tak np. w maju I832 roku nie mógł zaprezentować się w Turynie na dworze Karola Alberta (dalekiego krewnego) - z powodu wspominanych ciemnobłękitnych okularów ${ }^{44}$. $Z$ tych samych powodów zaniedbał wizytę $\mathrm{u}$ rosyjskiego dyplomaty Tatiszczewa w Wiedniu. Wiemy, że słaby wzrok stanowił też argument, pozwalający uniknąć służby na carskim dworze.

Bardziej dokuczliwa od izolacji towarzyskiej była jednak samotność duchowa i wspominana wielokrotnie niemożność swobodnej lektury - w niektórych okresach Krasiński skazany był na pomoc sekretarza lub przygodnych lektorów. Wiązała się z tym niemożność pisania, niekiedy wręcz zanik pasji twórczej („Nudami schodzą mi dni, nic robić nie mogę, ni czytać, ni pisać; staram się obserwować ludzi, jakże często się mylę"45), a przecież od dzieciństwa kształcony był na artystę. Wydaje się jednak, że choroba pozwoliła poecie w pewnej mierze uwolnić się od narzuconego przez rodzinę obciążenia i podjąć bardziej samodzielną drogę twórczą.

Już po kilku miesiącach choroby oczu Krasiński zaczął dostrzegać - paradoksalnie - pozytywne skutki swej sytuacji; I6 czerwca I832 roku zapewniał ojca: „Ta choroba nauczy mnie myśleć, dawniej tylko marzyć umiałem”46; w podobnym stylu pisał do Reeve'a, zdając relację z petersburskich zatrudnień: „Nauczyłem się myśleć. Stanę się dzikusem i poważnym myślicielem”47. Jak należy zatem rozumieć te przeświadczenia pisarza? W jakiej mierze zawierały ono zapowiedź realizowane-

42 M. Bieńczyk, op. cit., s. 99.

43 Pomijamy w tym miejscu znaczenie motywów oka i widzenia oraz choroby w twórczości literackiej Krasińskiego; okazują się one rzeczywiście ważne, bogate, zróżnicowane, ale inspirowane także innymi kontekstami niż choroba, wymagają więc oddzielnego opracowania.

44 Listy do ojca..., s. 293.

45 Ibidem, s. 291, list z 15 kwietnia 1832 roku.

46 Ibidem, s. 296.

47 Listy do Reeve'a..., t. 2, s. 39. Kilkakrotnie też zapewniał przyjaciela, że jego obecne poglądy to „nie jakiś nagły wybuch, to owoc długich medytacji” (ibidem, t. 2, s. 12). 
go później programu pisarskiego? Jak pamiętamy, Juliusz Kleiner swej monografii o Krasińskim nadał podtytuł: Dzieje myśli. Czy początkujący badacz literatury znał tę epistolograficzną wypowiedź portretowanego poety? Raczej nie (jak poinformował we wprowadzeniu, korzystał tylko $\mathrm{z}$ dzieł Krasińskiego w opracowaniu Tadeusza Piniego i w niewielkim stopniu z edycji Jana Czubka), a przecież mogłaby ona być doskonałym mottem dla jego monografii. Przypomnijmy początek tej pracy:

》Dzieje twórczości Krasińskiego jako całości jednolitej, rozwijającej się organicznie i konsekwentnie, są przede wszystkim dziejami myśli historią problemów wyłaniających się z życia narodowego, społecznego i osobistego, tudzież z ogólnej atmosfery umysłowej epoki, historią rozwiązywania tych problemów i stosowania rozwiązań. Jest to zjawisko wyjątkowe, nie wynikające $\mathrm{z}$ istoty twórczości poetyckiej, lecz płynące zarówno ze szczególnej organizacji psychicznej poety, jak ze szczególnych dążeń epoki, w której nie było całkiem odosobnione ${ }^{48}$.

Jest oczywiste, że syn generała Krasińskiego otrzymał staranne wykształcenie domowe, kontynuowal je, co prawda krótko, w trakcie studiów w Uniwersytecie Warszawskim, a następnie w Genewie, gdzie spotykał wybitne osobistości tego czasu. Według Kleinera, Szwajcaria dała młodemu pisarzowi środowisko intelektualne, ale jeszcze nie samodzielność myślenia, polski student nauczył się tam systematycznego przyswajania dorobku filozoficznego, jednak nie potrafil jeszcze wówczas stawiać pytań o najważniejsze sprawy ludzkiej egzystencji.

Pierwsze utwory Krasińskiego, utrzymane w manierze popularnego pisarstwa francuskiego i angielskiego (głównie Waltera Scotta), dowodzą, jak odtwórcze było młodzieńcze pisarstwo przyszłego autora Irydiona oraz Przedświtu. Przeważała w nim fantazja, niekiedy chorobliwe wręcz upodobanie w tajemniczości i cudowności, zamykanie fabuły w ramach marzenia sennego. Powstałe w połowie lat trzydziestych dramaty to świadectwa ogromnej przemiany twórczej, ale też mentalnej, jaka dokonała się w pisarzu. Krasiński wyzwolił się z epigońskiego naśladowania wzorów literackich pisarstwa zachodnioeuropejskiego o charakterze - w gruncie rzeczy - popularnym, odnajdując własny wyraz artystyczny. Kleiner szczegółowo przeanalizował zarówno poszczególne dzieła filozoficzne, jak też twórczość pisarzy, którzy kształtowali osobowość twórczą Krasińskiego oraz jego zaplecze intelektualne. Tezy historyka literatury warto uzupełnić przynajmniej jedną uwagą.

48 J. Kleiner, op. cit., s. VII. Podobnie o Krasińskim pisał też Wiesław Wohnout: „autor Nie-Boskiej, mózgowiec raczej niż improwizator, miłośnik ścisłego myślenia (także w polityce...) i logicznego wnioskowania" (Krasiński - żywy..., w: Krasiński żywy. Ksiqżka zbiorowa wydana staraniem Zwiqzku Pisarzy Polskich na Obczyźnie, Londyn 1959, s. 6). 
Ważnym elementem dojrzałego życia Krasińskiego stały się długotrwałe, troskliwie budowane przyjaźnie z najwybitniejszymi polskimi filozofami tego czasu: Augustem Cieszkowskim i Bronisławem Trentowskim ${ }^{49}$, ale też z Jerzym Lubomirskim ${ }^{50}$, Adamem Sołtanem, Edwardem Jaroszyńskim, Andrzejem, Kajetanem i Stanisławem Koźmianami. Korespondencja z nimi dowodzi udziału pisarza w najważniejszych dyskusjach intelektualnych i społecznych epoki. Choć autor Przedswitu nie został filozofem (ale jest autorem kilku pism o charakterze filozoficznym ${ }^{5 \mathrm{I}}$ ), to jednak żywo reagował na pytania stawiane przez ówczesną filozofię, podejmował dyskusję, proponując własne odpowiedzi i argumentację. Dzieje tych intelektualnych przyjaźni czekają na opisanie, mimo istniejącej już niewielkiej literatury przedmiotu ${ }^{52}$. Ich znaczenie jest tym donioślejsze, że wpłynęły także na zmianę formy pisarskiej Krasińskiego. Opisowość, podstawowa dominanta jego wczesnego pisarstwa, była systematycznie zastępowana dialogiem (czego oczywistą oznaką są dwa wielkie dramaty). Istotne wydają się też elementy dyskursu wewnętrznego (rozmowy myśli) w wypowiedziach literackich oraz użytkowych poety, ciągła polemika z interlokutorami, ale i z sobą samym. Ta zmiana formy: od opisowości w stronę rozmowy także wymaga szczegółowej analizy.

\section{Dramat aUtografów}

Korespondencja Krasińskiego ujawnia jeszcze jeden istotny problem związany z jego chorobą oczu. 3 sierpnia I832 roku poeta napisał do Gaszyńskiego:

\Pragnąłem zawsze zostawić Ci na pamiątkę kawałek jaki, choćby krótki i nędzny, ażebyś mógł, odczytując go, myśleć czasem o mnie. Ale że oczy mnie mocno bolą, nie mogłem przepisać sam. Otóż teraz znalazłem kogoś, co przepisał, i posyłam Ci ten ułamek napisany temu rok przeszło w Florencji, po wybuchnieniu naszego powstania. Jest to fikcja, w której ramach oprawiłem własne uczucia ${ }^{53}$.

49 Zob. Listy do Augusta Cieszkowskiego...

50 Z. Krasiński, Listy do Jerzego Lubomirskiego, oprac. i wstępem poprzedził Z. Sudolski, Warszawa 1965.

51 Z. Krasiński, Pisma filozoficzne i polityczne, wydał i notami opatrzył P. Hertz, Warszawa 1999.

52 Zob. np. Wydalony z Parnasu. Księga poświęcona pamięci Zygmunta Krasińskiego, pod red. J. Świdzińskiego, Poznań 2003, tu materiały poświęcone przyjaźni z Cieszkowskim.

53 Listy do Konstantego Gaszyńskiego..., s. 57. 
Fragment ten (a wypowiedzi o podobnym charakterze powtarzają się w dziesiątkach listów) odsłania bolesną rzeczywistość pisarstwa Krasińskiego: konieczność pomocy osób trzecich w realizacji zapisów. Rolę sekretarza pełnili czasowo: Konstanty Danielewicz, Konstanty Gaszyński, żona Eliza oraz przygodne osoby. Pisma o charakterze użytkowym bywały dyktowane osobom trzecim, dzieła literackie, zapisywane niestarannie, poeta oddawał do kopiowania; w okresach poprawy widzenia kontrolował odpisy, ale niesystematycznie i mało konsekwentnie. Także niemal wszystkie (po I832 roku) kopie dla wydawców tworzone były obcą ręką i nie było gwarancji ich autoryzowania.

Jeden z najtragiczniejszych paradoksów związanych z Krasińskim wiąże się z niemal całkowitą zatratą jego rękopisów ${ }^{54}$ - warszawskie archiwa Krasińskich płonęły w 1939 i 1944 roku, ich pozostałości w Złotym Potoku i Opinogórze uległy zniszczeniu w I945 - w czym miały udział zwycięskie wojska. Nie można więc ich analizować; spróbujmy jednak odnaleźć informacje o nich, zawarte we wcześniejszej literaturze przedmiotu. Najpełniejszy rejestr archiwaliów pisarskich autora Nie-Boskiej komedii znajdujemy w krytycznym wydaniu Pism z I9I2 roku, pod redakcją Jana Czubka. Dzieła poety w tej edycji są uporządkowane chronologicznie, łatwo więc śledzić ich losy we wzajemnych kontekstach. Przygotowując edycję, Czubek otrzymał z archiwum Krasińskich wszystkie materiały związane z poetą, dysponował też jakimś wykazem dokumentów znajdujących się w obcych rękach i zazwyczaj uzyskiwał ich kopie ${ }^{55}$ (nie dotyczyło to listów, te pozostawały bowiem poza planami wydawniczymi). Jakie wnioski wynikają z zestawienia opracowanego przez Czubka?

Archiwum rękopisowe Krasińskiego było stosunkowo bogate i wielokrotnie porządkowane ${ }^{56}$. Tak np. rękopis oznaczony numerem I zawierał najwcześniejsze próby pisarskie, czyli materiały z lat I823-I829, stanowił kodeks oprawny w półskórek, złożony z papierów różnogatunkowych i różnoformatowych. Rękopisy nr 3 i 4 to czystopis i brulion Pana trzech pagórków (z 1828 roku). Można przypuszczać, że cała wczesna twórczość autora powieści Wtadystaw Herman i dwór jego została zarchiwizowana; trudno jednak określić czas tych działań. Kodeksy oprawiane w podobny sposób, ze złoconymi napisami na grzbiecie sugerują długofalową,

54 „Pozostało [...] utrapienie związane z brakiem podstawowych dokumentów [...] życia i twórczości” Krasińskiego - napisała autorka monografii o Bibliotece Krasińskich, Halina Tchórzewska-Kabata (Zygmunt Krasiński - duma i utrapienie potomków i rodziny, w: Zygmunt Krasiński. Dylematy egzystencji..., s. 191).

55 Z. Krasiński, Pisma. Wydanie Jubileuszowe, t. 1-8, oprac. J. Czubek, Kraków 1912.

56 Zob. H. Tchórzewska-Kabata, Pod znakiem światta. Biblioteka Ordynacji Krasińskich 1844-1944, Warszawa 2010. 
konsekwentną pracę, także pisarza, który powracał do swych rękopisów, nanosząc poprawki i uzupełnienia (utrwalone innym piórem, dlatego widoczne).

Opisy Czubka dostarczają ważnego materiału do interesującego nas zagadnienia, okazuje się bowiem, że np. część czystopisu Agaj-Hana została sporządzona obcą ręką̨: „poeta wyręczył się [...] ręką cudzą, która na ogół ze swego zadania wywiązała się wcale dobrze, choć nie obeszło się także bez kilku pomyłek i jednej zmiany na gorsze; na szczęście posiadamy brulion, który nam daje pierwotny tekst utworu" ${ }^{57}$ - konstatował badacz archiwum. Czubek sugerował, że zlecenie przepisania części rękopisu osobie trzeciej mogło wynikać „z powodu bólu oczu”. Także autograf brulionowy zawierał ślady choroby wzroku poety, który na swe dzieło nanosił dwa rodzaje poprawek $^{58}$. Część z nich została napisana innym atramentem, ale też znacznie większymi literami, co jest cechą charakterystyczną pisma osób niedowidzących.

Rękopisy Krasińskiego powstające od połowy I83I roku coraz częściej wychodzity spod obcej ręki. W przypadku rękopisu kierowanego do drukarni byłoby to czymś naturalnym, a taki jest przypadek Nie-Boskiej komedii, pisanej co najmniej trzema charakterami pisma. Niespodzianką jest natomiast inny fakt: poeta przechowywał rękopis drukarski (co było ewenementem w XIX wieku, rękopisy nie były bowiem zwracane autorom), nie miał natomiast w archiwum, tak pojemnym, własnego czystopisu. Można zadać pytanie: dlaczego?

Kolejny wielki dramat, Irydion, zachował się tylko w kopii, ale z poprawkami autora, który własną ręką wpisał nowe motto. Czubek określił te poprawki jako robione „tu i ówdzie”, „z pamięci”"59; z pamięci, znaczy: niedokładnie, bez zaglądania do przekazu podstawowego.

Analiza opisów sporządzonych przez Czubka prowadzi do następujących wniosków:

- wczesna twórczość poety zachowała się w autografach;

- dla wielu utworów z późniejszych lat istniały tylko kopie obcej ręki,

- dla niektórych utworów zachowały się tylko kopie sporządzone późno, już po śmierci poety (ręką osób pracujących w archiwum Krasińskich, np. Ignacego Janickiego).

I tu dochodzimy do najbardziej dramatycznego elementu tej relacji, a wiąże się on z metodami pracy w archiwum Krasińskich. $Z$ istniejącej literatury przedmiotu ${ }^{60}$ można wysnuć przypuszczenie, że archiwiści przepisywali dokumenty, zwłaszcza te, które były mało czytelne, zapisane ręką niedowidzącego poety. Robili to, bo

57 Ibidem, t. 1, s. 591.

58 Ibidem, t. 1, s. 589.

59 Ibidem, t. 2, s. 386.

60 Zob.: M. Mazanowski, Mtodociane przektady Zygmunta Krasińskiego, w: Księga pamiątkowa ku uczczeniu setnej rocznicy urodzin Zygmunta Krasińskiego, t. 1, Lwów 1912; I. Baranowski, Biblioteka Ordynacji br. Krasinskich w Warszawie, „Ziemia” 1911, nr 35. 
rodzina chciała mieć dokumentację przejrzystą, uporządkowaną, jednoznacznie brzmiącą dla zainteresowanych twórczością Krasińskiego. Po przepisaniu oryginały niszczono - jako nieczytelne, stanowiące dowód choroby autora.

Dlaczego rodzina to robiła? Może przyjęła przeświadczenie poety, że przyczyną ślepych oczu było zranione serce? A może bała się, że mikroskop i soczewka pozwolą wyczytać z tych rękopisów więcej, niż chciało ujawnić otoczenie pisarza?

\section{ZAKOŃCZENIE}

Choroba wzroku Krasińskiego i epistolarne relacje o jej przebiegu oraz sposobach przezwyciężania narzuconych przez nią ograniczeń są szczególnym świadectwem doświadczenia egzystencjalnego autora Przedświtu, ale doskonale wpisują się też w sytuację osób niewidomych czy niedowidzących w XIX wieku ${ }^{6 \mathrm{r}}$. Z jednej strony, mamy intensywne próby - niekiedy skuteczne - poszukiwania środków zaradczych (szkła poprawiające widzenie, terapie wzmacniające organizm), z drugiej strony deprecjonujący niekiedy stosunek otoczenia do naznaczonych cierpieniem, ale też inicjatywy zmierzające do przełamania istniejących stereotypów obyczajowych, czego najważniejszym świadectwem na ziemiach polskich będą (dopiero dwudziestowieczne) dzieła Róży Czackiej ${ }^{62}$, spokrewnionej z Krasińskim przez babkę, Antoninę z Czackich.

Sytuacja autora Irydiona odsłania ponadto jedno indywidualne oblicze zjawiska: przed wynalezieniem alfabetu Braille' ${ }^{6}{ }^{6}$ i opartej na nim maszyny do pisania niewidomy autor skazany był na pomoc, najczęściej niefachową, otoczenia. W niektórych okresach życia Krasiński tworzył w warunkach takich jak w epoce rękopisu - nie posiadał autografów, nie uczestniczył też czynnie w procesach wydawniczych ${ }^{64}$ swych utworów, przekazując je czytelnikom z wszystkimi wadami typowymi dla nieautoryzowanych kopii rękopiśmiennych co stało się źródłem wielu problemów edytorskich. W tym kontekście wymowne wydają się starania innych pisarzy niedo-

61 Mogą także stanowić interesujący rozdział w jakże bogatej historii chorób romantyków. Zob. np. L. Libera, Mickiewicz i medycyna. Szkice romantyczne, Zielona Góra 2010.

62 Czacka utraciła wzrok we wczesnej młodości, po czym podjęła się organizowania opieki nad niewidomymi. W 1910 roku założyła Towarzystwo Opieki nad Ociemniałymi, podejmowała też liczne działania jako franciszkanka, m.in. budowę Zakładu dla Niewidomych w Laskach koło Warszawy. Zob. J. Stabińska, Matka Elizbieta Róża Czacka, wyd. 2 uzup., Laski [1989].

63 Powszechne stosowanie zyskał dopiero po $1879 \mathrm{r}$.

64 Nałożyły się na to ograniczające działania cenzury, zmuszające Krasińskiego do anonimowego publikowania swych dzieł i wynikające stąd zaburzenia w przebiegu właściwego dla XIX wieku procesu wydawniczego. Zob. T. Winek, „Irydiona” boje z cenzura, w: Literatura w granicach prawa (XIX-XX w.), pod red. K. Budrowskiej, E. Dąbrowicz, M. Lula, Warszawa 2013. 
64

widzących używających maszyny do pisania (np. Bolesława Prusa), która umożliwiła poszerzenie zakresu władzy autora nad tekstem.

\section{Bibliografia:}

Bieńczyk M., Czarny cztowiek. Krasiński wobec śmierci, Warszawa 1990;

Burkot S., Polskie podróżopisarstwo romantyczne, Warszawa 1988;

Danek D., Śmierć wewnętrzna, Gdańsk 2012;

Kallenbach J., Zygmunt Krasinski. Życie i twórczość lat mtodych (1812-1838), t. 1-2, Lwów 1904;

Kleiner J., Zygmunt Krasiński. Dzieje myśli, Warszawa 1912;

Korzeniewicz M., Romantyczne „widzenie” i „styszenie” świata w „Uspokojeniu”, „Pamiętnik Literacki” 1979, z. 2, s. 101-123;

Libera L., Mickiewicz i medycyna. Szkice romantyczne, Zielona Góra 2010;

Listy Zygmunta Krasińskiego:

Listy do Adama Sottana, oprac. i wstępem poprzedził Z. Sudolski, Warszawa 1970;

Listy do Augusta Cieszkowskiego, Edwarda Jaroszyñskiego, Bronistawa Trentowskiego, t. 1-2, oprac. i wstępem poprzedził Z. Sudolski, Warszawa 1988;

Listy do Delfiny Potockiej, t. 1-3, oprac. i wstępem poprzedził Z. Sudolski, Warszawa 1975;

Listy do Henryka Reeve, t. 1-2, tłum. A. Olędzka-Frybesowa, oprac., wstępem, kroniką i notami opatrzył P. Hertz, Warszawa 1980;

Listy do Jerzego Lubomirskiego, oprac. i wstępem poprzedził Z. Sudolski, Warszawa 1965;

Listy do Konstantego Gaszyńskiego, oprac. i wstępem poprzedził Z. Sudolski, Warszawa 1971;

Listy do ojca, oprac. i wstępem poprzedził S. Pigoń, Warszawa 1963;

Listy do różnych adresatórw, t. 1-2, zebrał, oprac. i wstępem poprzedził Z. Sudolski, Warszawa 1991;

Pini T., Krasiński. Życie i twórczość, Poznań 1928;

Sudolski Z., Krasiński. Opowieś́ biograficzna, Warszawa 1997;

Tchórzewska-Kabata H., Pod znakiem światta. Biblioteka Ordynacji Krasinskich 1844-1944, Warszawa 2010;

Zygmunt Krasiński. Dylematy egzystencji - problemy biografii, pod red. M. Bizior-Dombrowskiej, Toruń 2014; tu zwłaszcza artykuły:

Danek D., Inne spojrzenie na Krasinskiego. Tezy, s. 99-107;

Lachowicz P., Krasiński - tragiczna biografia - tragiczna twórczość. Listy w kontekście tragizmu Waltera Muschga, s. 86-98;

Tchórzewska-Kabata H., Zygmunt Krasiñski - duma i utrapienie potomków i rodziny, s. 173-191;

Ziołowicz A., „Cztowiek wewnętrzny we mnie”. Z problematyki wyobraźni i autorefleksji antropologicznej Krasińskiego, s. 29-44.

SŁowa klucze: Zygmunt Krasiński, utrata wzroku, autografy Krasińskiego, powstanie listopadowe, romantyczne choroby 


\section{Teresa Winek}

An Eye, Glasses, and Autographs: Contributions to the Literary History of Zygmunt Krasinski

Early works by Zygmunt Krasinski were full of travel reports and descriptions of acknowledged landscapes. They demonstrate a particular visual sensitivity of the young writer. Starting in 1832 an eye disease prevented the development of this writing. The poet saddled with amblyopia wrote about his difficulty in letters to family and friends.

The illness was treated by him as a psychosomatic - the effect of disturbances on the way between the eye and the heart that was wounded by the inability to participate in the November Uprising. The consequences of the disease (restrictions of social life, loneliness, inability to read) were recognised by Krasinski as circumstances conducive to intellectual work (in his writings the role of internal dialogue and philosophical debate systematically increased). The disease, however, imposed unnatural conditions on the writer's work (the need for a secretary assistance), which limited the number of autographs, further reduced by the family in the course of organizing the family archive.

KeY words: Zygmunt Krasinski, amblyopia, Krasinski's autographs, November Uprising 